\title{
Gram-Scale Synthesis of Highly Active and Durable Octahedral PtNi Nanoparticle Catalysts for Proton Exchange Membrane Fuel Cell
}

Choi, Juhyuk; Jang, Jue-Hyuk; Roh, Chi-Woo; Yang, Sungeun; Kim, Jiwhan; Lim, Jinkyu; Yoo, Sung Jong; Lee, Hyunjoo

Published in:

Applied Catalysis B: Environmental

Link to article, DOI:

10.1016/j.apcatb.2017.12.016

Publication date:

2018

Document Version

Peer reviewed version

Link back to DTU Orbit

Citation (APA):

Choi, J., Jang, J-H., Roh, C-W., Yang, S., Kim, J., Lim, J., Yoo, S. J., \& Lee, H. (2018). Gram-Scale Synthesis of Highly Active and Durable Octahedral PtNi Nanoparticle Catalysts for Proton Exchange Membrane Fuel Cell. Applied Catalysis B: Environmental, 225, 530-537. https://doi.org/10.1016/j.apcatb.2017.12.016

\section{General rights}

Copyright and moral rights for the publications made accessible in the public portal are retained by the authors and/or other copyright owners and it is a condition of accessing publications that users recognise and abide by the legal requirements associated with these rights.

- Users may download and print one copy of any publication from the public portal for the purpose of private study or research.

- You may not further distribute the material or use it for any profit-making activity or commercial gain

- You may freely distribute the URL identifying the publication in the public portal 


\section{Accepted Manuscript}

Title: Gram-Scale Synthesis of Highly Active and Durable Octahedral PtNi Nanoparticle Catalysts for Proton Exchange Membrane Fuel Cell

Authors: Juhyuk Choi, Jue-Hyuk Jang, Chi-Woo Roh, Sungeun Yang, Jiwhan Kim, Jinkyu Lim, Sung Jong Yoo,

Hyunjoo Lee

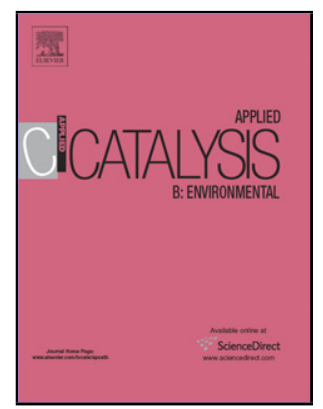

PII:

S0926-3373(17)31165-7

DOI:

Reference: https://doi.org/10.1016/j.apcatb.2017.12.016

To appear in: APCATB 16251

Received date: Applied Catalysis B: Environmental

Revised date: 5-7-2017

Accepted date:

Please cite this article as: Juhyuk Choi, Jue-Hyuk Jang, Chi-Woo Roh, Sungeun Yang, Jiwhan Kim, Jinkyu Lim, Sung Jong Yoo, Hyunjoo Lee, GramScale Synthesis of Highly Active and Durable Octahedral PtNi Nanoparticle Catalysts for Proton Exchange Membrane Fuel Cell, Applied Catalysis B, Environmental https://doi.org/10.1016/j.apcatb.2017.12.016

This is a PDF file of an unedited manuscript that has been accepted for publication. As a service to our customers we are providing this early version of the manuscript. The manuscript will undergo copyediting, typesetting, and review of the resulting proof before it is published in its final form. Please note that during the production process errors may be discovered which could affect the content, and all legal disclaimers that apply to the journal pertain. 


\section{Gram-Scale Synthesis of Highly Active and Durable Octahedral PtNi Nanoparticle Catalysts for Proton Exchange Membrane Fuel Cell}

Juhyuk Choi ${ }^{a}$, Jue-Hyuk Jang ${ }^{b}$, Chi-Woo Roh ${ }^{a}$, Sungeun Yang ${ }^{c}$, Jiwhan Kim ${ }^{a}$, Jinkyu Lim ${ }^{a}$, Sung Jong Yoo ${ }^{b, *}$, Hyunjoo Lee $e^{a, *}$

${ }^{a}$ Department of Chemical and Biomolecular Engineering, Korea Advanced Institute of Science and Technology, Daejeon 34141, Republic of Korea

${ }^{\mathrm{b}}$ Fuel Cell Research Center, Korea Institute of Science and Technology, Seoul 02792, Republic of Korea

cDepartment of Physics, Technical University of Denmark, Kongens Lyngby 2800, Denmark

\section{Graphical Abstract}

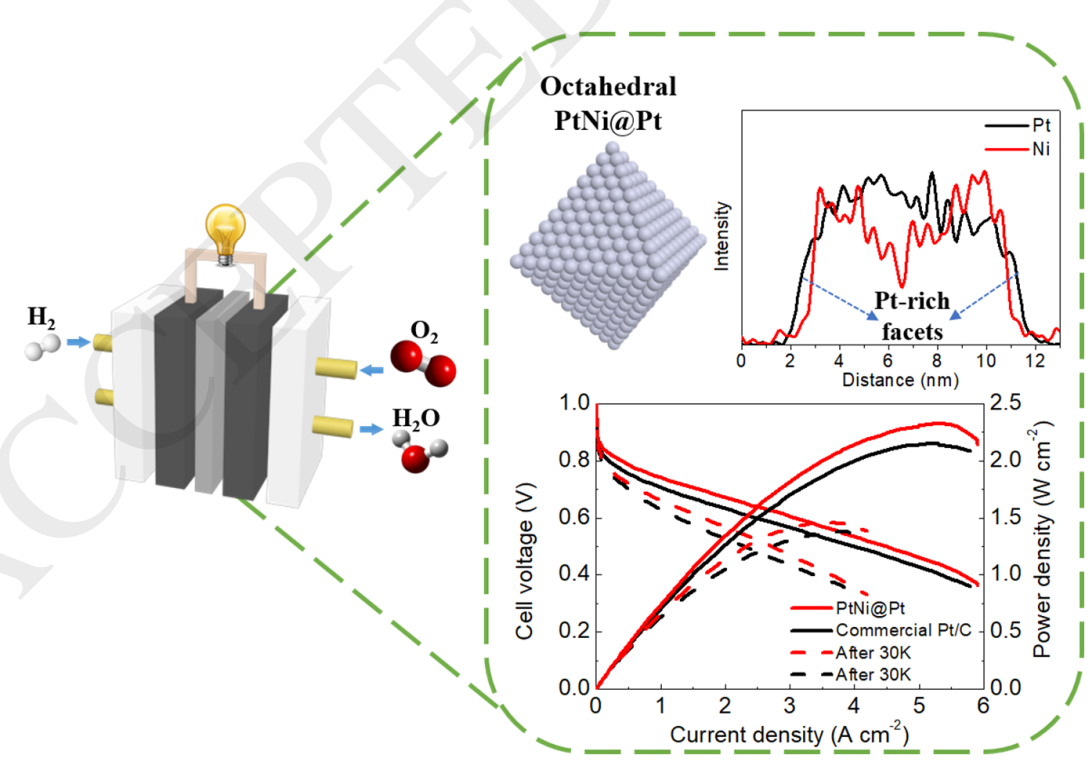

\footnotetext{
*Corresponding authors: ysj@ kist.re.kr (S. J. Yoo); azhyun@kaist.ac.kr (H. Lee)
} 


\title{
Highlights
}

- Octahedral PtNi nanoparticles with Pt overlayers supported on the carbon (PtNi@ Pt/C) were synthesized at a gram scale.

- The Pt overlayers could prevent Ni leaching, resulting in enhanced activity and durability in half cell tests.

- The PtNi@Pt/C was successfully applied as a cathode catalyst in a single cell of PEMFC.

- The PtNi@Pt/C showed enhanced activity and durability in the single cell tests compared to the commercial Pt/C.

\begin{abstract}
Proton exchange membrane fuel cells (PEMFC) are regarded as a promising renewable energy source for a future hydrogen energy society. However, highly active and durable catalysts are required for the PEMFCs because of their intrinsic high overpotential at the cathode and operation under the acidic condition for oxygen reduction reaction (ORR). Since the discovery of the exceptionally high surface activity of $\mathrm{Pt}_{3} \mathrm{Ni}(111)$, the octahedral $\mathrm{PtNi}$ nanoparticles have been synthesized and tested. Nonetheless, their milligram-scale synthesis method and poor durability make them unsuitable for the commercialization of PEMFCs. In this study, we focus on gram-scale synthesis of octahedral PtNi nanoparticles with Pt overlayers (PtNi@Pt) supported on the carbon, resulting in enhanced catalytic activity and durability. Such PtNi@Pt catalysts show high mass activity (1.24 $\mathrm{A} \mathrm{mg}_{\mathrm{Pt}^{-1}}$ ) at $0.9 \mathrm{~V}$ (vs RHE) for the ORR, compared to commercial $\mathrm{Pt} / \mathrm{C}\left(0.22 \mathrm{~A} \mathrm{mg}_{\mathrm{Pt}^{-1}}\right)$. Single-cell performance and electrochemical impedance spectroscopy (EIS) were also tested. The PtNi@Pt catalysts showed enhanced current density of $3.1 \mathrm{~A} \mathrm{~cm}^{-2}$ at $0.6 \mathrm{~V}$ in $\mathrm{O}_{2}$ flow while the commercial $\mathrm{Pt} / \mathrm{C}$ had the value of $2.5 \mathrm{~A} \mathrm{~cm}^{-2}$. After 30,000 cycles of the accelerated degradation test (ADT), the PtNi@Pt still showed better
\end{abstract}


performance than the commercial Pt/C in a single-cell system. The Pt layers deposition could enhance the catalytic performance and durability of octahedral PtNi nanoparticles.

Keywords: Proton exchange membrane fuel cells; oxygen reduction reaction; Pt overlayers; octahedral PtNi; durability

\section{Introduction}

PEMFC is an electrochemical energy conversion device that can directly convert hydrogen energy into electricity with high efficiency and zero emission. However, a large amount of Pt catalyst used, poor durability, and deficient performance due to the sluggish kinetics of the ORR at the cathode are major obstacles to its commercialization [1]. Thus, it is important to develop more active and durable catalysts for application as cathode catalysts in PEMFCs.

Pt-transition metal (where TM is $\mathrm{Fe}, \mathrm{Co}, \mathrm{Ni}, \mathrm{Cu}, \mathrm{Mo}$, etc.) alloy catalysts have been actively studied for application as catalysts in the cathode. Pt-TM alloys show enhanced activity for ORR because of the correlation with Pt d-band center down-shifts, which is attributed to the weakening of the binding energy between Pt and intermediate oxygen species during the reaction [2-13]. Among such Pt-based alloy catalysts, shape-controlled octahedral PtNi nanoparticles are considered as excellent ORR electrocatalysts because of their superior activity. Stamenkovic and coworkers suggested that the $\mathrm{Pt}_{3} \mathrm{Ni}$ (111) single crystal surface, which consists of a top-most layer of Pt and subsurface of Ni, would show high ORR activity [14]. They demonstrated that the subsurface Ni is able to modify the electronic structure of Pt, inducing high ORR activity. Many researchers have dedicated to develop well-defined PtNi (111) or octahedral PtNi nanoparticles [15-27]. Because of their exceptional ORR activity, octahedral PtNi nanoparticles have been expected to play a central role in the commercialization of PEMFC. 
However, conventional syntheses of octahedral PtNi nanoparticles are limited to a solutionbased method in which organic surfactants are used to control the nanoparticle shape. The organic surfactants contaminate the catalyst surface and additional steps are required to remove them. Another issue is that the octahedral PtNi nanoparticles are produced with only milligramscales using the solution-based methods [15-27]. Zhang et al. reported the gas-phase method synthesizing octahedral PtNi nanoparticles, which has a potential for large scale syntheses [25]. Unfortunately, the octahedral PtNi nanoparticles also showed deficient durability. Ni is easily oxidized and leached from the nanoparticles in the acidic or oxidative conditions under which PEMFCs operate [28-31]. A Pt shell would be desired to protect the Ni atoms from leaching. An electrochemical $\mathrm{Cu}$ underpotential deposition (UPD) and Pt galvanic replacement method have been used to deposit a Pt monolayer on substrate nanoparticles [32-36].

In this study, we synthesized the octahedral PtNi nanoparticles using the gas-phase synthesis method, then Pt layers were deposited on the surfaces of octahedral PtNi nanoparticles by $\mathrm{Cu}$ UPD method and galvanic replacement of $\mathrm{Cu}$ with $\mathrm{Pt}$. The octahedral PtNi@Pt catalysts were successfully prepared with a gram scale. Their morphology was investigated by TEM characterizations, and the electrochemical measurements were performed using both half-cell and single-cell tests and compared with the commercial Pt/C catalyst.

\section{Experimental}

\subsection{Synthesis of octahedral PtNi nanoparticles on carbon supports}

The octahedral PtNi nanoparticles were synthesized in a $\mathrm{H}_{2} / \mathrm{CO}$ gas flow system [25]. A carbon Vulcan ${ }^{\circledR} \mathrm{XC}-72 \mathrm{R}$ (Cabot) support was pre-treated overnight in air at $300{ }^{\circ} \mathrm{C}$ to remove the absorbed water. Then, $1.25 \mathrm{mmol}$ of $\mathrm{Pt}(\mathrm{acac})_{2}$ (Sigma-Aldrich, 97\%) and $0.81 \mathrm{mmol}$ of $\mathrm{Ni}$ (acac) 2 (Sigma-Aldrich, 95\%) were dissolved in $60 \mathrm{~mL}$ of acetone (SAMCHUN, 99.5\%). 
The homogeneous green solution was dripped onto $1.0 \mathrm{~g}$ of thermally pre-treated carbon support while stirring at 600 RPM. After removing the residual acetone in a drying oven, the mixture was reduced using a tube furnace at a heating rate of $5{ }^{\circ} \mathrm{C} \min ^{-1}$ to $200{ }^{\circ} \mathrm{C}$; then the temperature was maintained for $1 \mathrm{~h}$ in flowing $\mathrm{H}_{2} / \mathrm{CO}\left(6.5 / 156 \mathrm{~cm}^{3} \mathrm{~min}^{-1}\right)$. The gas flow was continued until the mixture cooled to room temperature, and then the flow was switched to $\mathrm{N}_{2}$ gas. The synthesized octahedral PtNi catalyst was left under ambient conditions for 15 min to allow removal of adsorbed CO, and then washed with a mixture of ethanol (SAMCHUN, 99.9\%) and deionized water with centrifugation at 8000 RPM.

\subsection{Cu UPD and Pt galvanic replacement on the octahedral PtNi (PtNi@Pt)}

Deposition of $\mathrm{Pt}$ layers on the octahedral $\mathrm{PtNi}$ nanoparticles was performed using $\mathrm{Cu}$ underpotential deposition (UPD) and the Pt galvanic replacement method [37]. The octahedral $\mathrm{PtNi} / \mathrm{C}$ was dispersed in $50 \mathrm{mM} \mathrm{H} \mathrm{SO}_{4}$ (Sigma-Aldrich, 99.999\%) with Ar purging. Next, $\mathrm{CuSO}_{4}$ (Sigma-Aldrich, 99.99+\%) was added to the above solution (to make $2 \mathrm{mM} \mathrm{CuSO}_{4}$ ), and a $5 \times 10 \mathrm{~cm}$ piece of $\mathrm{Cu} 300$ mesh was immersed in the solution with stirring at $800 \mathrm{RPM}$ for $30 \mathrm{~min}$. The $\mathrm{Cu} 300$ mesh was removed from the solution, then $0.05 \mathrm{mM}$ of $\mathrm{K}_{2} \mathrm{PtCl}_{4}$ (SigmaAldrich, 98\%) solution was added into the solution, producing Pt overlayers on the octahedral PtNi nanoparticles (PtNi@Pt). The PtNi@Pt catalysts were washed with water during the filtration. Then, the Cu UPD and Pt replacement were repeated one more time to deposit a thick Pt shell. The Pt content in the PtNi@Pt/C catalyst was 21.2 wt $\%$.

\subsection{Electrochemical measurements}

All electrochemical measurements were performed using a CHI 730E potentiostat and a threeelectrode cell at $25{ }^{\circ} \mathrm{C}$. The three electrode system consists of a glassy carbon working electrode (Pine), a $3 \mathrm{M} \mathrm{NaCl}$ (99\%, Sigma-Aldrich) solution-saturated $\mathrm{Ag} / \mathrm{AgCl}$ reference 
electrode (BASi), and a twisted Pt wire counter electrode. All potentials reported in this work were referenced to a reversible hydrogen electrode (RHE), which was measured at the zerocurrent point of the hydrogen evolution and oxidation reaction in a $\mathrm{H}_{2}$-saturated $0.1 \mathrm{M} \mathrm{HClO}_{4}$ (70\%, Sigma Aldrich) solutions using a rotating Pt electrode. The catalyst ink was made by mixing deionized water ( $3 \mathrm{~mL}, 18.2 \mathrm{M} \Omega \mathrm{cm}$ ), isopropyl alcohol (2 $\mathrm{mL}$, Junsei, $99.7 \%$ ), and 5 wt $\%$ Nafion ${ }^{\circledR}$ ionomer (20 $\mu \mathrm{L}$, Sigma-Aldrich), then it was sonicated in ultrasonic bath for 20 min. The mixed ink were dispersed onto the glassy carbon electrode and dried at ambient condition. The Pt loading amount was $12.1 \mu \mathrm{g} \mathrm{cm}{ }^{-2}$ for all the half-cell measurements. The PtNi-based catalysts activation were performed by repeating 10 cycles of cyclic voltammetry (CV) from 0.05 to $1.0 \mathrm{~V}$ in Ar-saturated $0.1 \mathrm{M} \mathrm{HClO}_{4}$ solution at a scan rate of $100 \mathrm{mV} \mathrm{s}^{-1}$. The commercial Pt/C (Johnson Matthey, Pt 20\%) was activated by repeating 50 cycles of CV at the same condition. The electrochemically active surface area (ECSA) was calculated by averaging the integrated areas of $\mathrm{H}_{\mathrm{ads}} / \mathrm{H}_{\mathrm{des}}$ using $210 \mu \mathrm{C} \mathrm{cm}^{-2}$. Linear sweep voltammetry (LSV) curves were obtained from 0.05 to $1.1 \mathrm{~V}$ in $\mathrm{O}_{2}$-saturated $0.1 \mathrm{M} \mathrm{HClO}_{4}$ solution at a scan rate of $10 \mathrm{mV} \mathrm{s}^{-1}$ and a rotation rate of $1600 \mathrm{RPM}$ with iR compensation. The electrocatalytic mass and specific activity were evaluated using the Koutecky-Levich equation at $0.9 \mathrm{~V}$ from the LSV data. The accelerated durability tests (ADT) were carried out using cyclic voltammetry from 0.6 to $1.0 \mathrm{~V}$ for 5,000 or 10,000 cycles in $\mathrm{O}_{2}$-saturated $0.1 \mathrm{M} \mathrm{HClO}_{4}$ at a scan rate of 100 $\mathrm{mV} \mathrm{s}^{-1}$.

\subsection{MEA fabrication and single cell tests}

The membrane electrode assemblies (MEAs) were prepared using a catalyst coated membrane (CCM) method. The active area of the electrodes was $5 \mathrm{~cm}^{2}$. The catalyst ink composing of the catalysts, Nafion ${ }^{\circledR}$ ionomer, and 2-propanol (Burdick\&Jackson, 99.99\%)) was sprayed onto a Nafion 211 membrane. The commercial Pt/C (TKK, Pt $46.5 \mathrm{wt} \%$ ) was utilized as the anode 
catalyst. The cathode was prepared using the commercial Pt/C (Johnson Matthey, Pt 20 wt\%) or the octahedral PtNi@Pt/C. The Pt loading was $0.2 \mathrm{mg} \mathrm{cm}^{-2}$ on both the anode and the cathode. A commercial gas diffusion layer (39BC, SGL) was utilized. Single cell performance was examined using a fuel cell station $(\mathrm{CNL})$ at $80{ }^{\circ} \mathrm{C}$. For the electrochemical analyses, $\mathrm{CV}$ and electrochemical impedance spectroscopy (EIS) were measured with a potentiostat (Biologics, SP-300). $\mathrm{H}_{2}$ with $100 \%$ relative humidity (RH) was supplied to the anode. $\mathrm{O}_{2}$ or air with $100 \%$ RH was supplied to the cathode for current density and voltage (I-V) polarization and EIS measurements. $\mathrm{N}_{2}$ with $100 \% \mathrm{RH}$ was supplied to the cathode for the $\mathrm{CV}$ measurements. The I-V polarization curves were obtained from open circuit voltage $(\mathrm{OCV})$ to $0.35 \mathrm{~V}$ with 0.8 bar $_{\mathrm{g}}$. The $\mathrm{CV}$ was measured from 0.05 to $1.2 \mathrm{~V}$ at a scan rate of $50 \mathrm{mV} \mathrm{s}^{-1}$. The EIS was measured from $10 \mathrm{mHz}$ to $10 \mathrm{kHz}$ at a cell voltage of $0.85 \mathrm{~V}$. The ADT was performed at a scan rate of $50 \mathrm{mV} \mathrm{s}^{-1}$ from $0.6 \mathrm{~V}$ to $1.0 \mathrm{~V}$ for 30,000 cycles with a cathode feed of $\mathrm{N}_{2}$ with $100 \% \mathrm{RH}$.

\subsection{Characterizations}

The nanoparticle morphology was confirmed by Tecnai TF30 ST transmission electron microscopy (TEM, $200 \mathrm{kV}$ ). High angle annular dark field scanning TEM (HAADF-STEM), energy dispersive spectroscopy (EDS)-mapping images and line-scanning profiles were taken using a Cs-corrected Titan cubed G2 60-300 TEM (200 kV). The crystalline structure of the catalyst nanoparticles was characterized using RiGAKU D/MAX-2500 X-ray diffraction patterns (XRD). The Pt and Ni content in the PtNi catalysts were analyzed using Agilent inductively coupled plasma optical emission spectroscopy 720 (ICP-OES). The concentration of leached Pt or $\mathrm{Ni}$ ions in the $0.1 \mathrm{M} \mathrm{HClO}_{4}$ electrolyte was measured using Agilent inductively coupled plasma mass spectroscopy 7700S (ICP-MS). X-ray absorption near-edge structure (XANES) spectra of the Pt L3 edge were obtained using the Nano XAFS beamline (Pohang Light Source). 


\section{Results and Discussion}

\subsection{Octahedral PtNi@Pt/C catalysts}

The octahedral PtNi/C nanoparticles were obtained by reducing Pt and Ni precursors dispersed on the carbon support in the presence of $\mathrm{CO}$ in a gas phase. The $\mathrm{CO}$ gas is well-known as a shape-controlling agent for producing (111) facets $[17,25]$. The gas-phase method enables gram-scale syntheses of octahedral $\mathrm{PtNi} / \mathrm{C}$ catalysts without using any organic surfactant. The Pt overlayers could be deposited on the octahedral PtNi nanoparticles using the $\mathrm{Cu}$ UPD method with Pt galvanic replacement. When the as-made octahedral PtNi/C were dispersed in the acidic solution, the surface Ni atoms were easily leached leaving Pt abundant surface [38, 39]. To distinguish the effect of the acid treatment and the formation of Pt overlayers, the asmade $\mathrm{PtNi} / \mathrm{C}$ treated in $50 \mathrm{mM} \mathrm{H} \mathrm{SO}_{4}$ solution and the PtNi@Pt/C were compared in this work.

The TEM images of the as-made PtNi and PtNi@Pt nanoparticles are shown in Figure 1. The nanoparticles clearly show the octahedral shape. The sizes of the nanoparticles were estimated by measuring 'edge to edge' length within a nanoparticle in various TEM images. The average size increased from $7.10 \mathrm{~nm}$ to $8.08 \mathrm{~nm}$ after forming the Pt overlayers. Considering that the distance between the Pt(111) planes is $2.27 \AA$, approximately $2.2 \mathrm{Pt}$ overlayers were deposited on the octahedral PtNi nanoparticles [40]. Figure 2 shows HAADF-

STEM and EDX-mapping images for the as-made PtNi and PtNi@Pt nanoparticles. The PtNi@Pt nanoparticle clearly demonstrated more Pt at the surface. The line-scan image also supports the Pt-rich facets. Figure S1 shows the XRD patterns of the as-made PtNi and PtNi@Pt. The patterns show Pt-Ni alloy structure, and they were similar without noticeable difference. In the case of PtNi@Pt, no XRD peaks for Pt domain were observed. It indicates that Pt overlayers were deposited on the octahedral PtNi nanoparticles, not forming separate $\mathrm{Pt}$ 
nanoparticles. Figure S2 shows that the octahedral PtNi@Pt/C catalyst can be easily prepared at a gram scale in one batch.

Forming the Pt overlayers is the key for the successful synthesis. Especially, the concentration of Pt precursor and the stirring rate during Pt galvanic replacement affected the formation of smooth Pt overlayers significantly. Figure 3 shows the TEM images of the resulting nanoparticles when the concentration of $\mathrm{K}_{2} \mathrm{PtCl}_{4}$ was varied during the replacement. The high Pt concentration produced dendritic shape. The EDS images in Figure 3 confirms that the Pt was deposited on the octahedral PtNi nanoparticle with a dendritic shape of shell. High Pt-Pt bond energy often induces Pt atoms deposited with a dendrite structure rather than a thin layer [41-43]. Xia et al. nicely showed that the balance between the deposition rate and diffusion rate of Pt atoms on Pd surface would enable the formation of smooth Pt overlayer on Pd nanoparticles [44]. Figure S3 shows the TEM images of the nanoparticles synthesized under various stirring rates during the replacement. When the stirring rate is low, the dendritic Pt shell was also observed. The concentration of Pt precursor or the stirring rate would control the mass transfer rate of the Pt precursors into the nanoparticle surface. The higher concentration would make the mass transfer faster, subsequently inducing the evolution of dendritic Pt shell. The lower stirring rate would cause the depletion of the Pt precursors near the nanoparticle surface, making the mass transfer rate higher into the nanoparticle surface. A low Pt concentration of $0.05 \mathrm{mM}$ and a high stirring rate of $800 \mathrm{RPM}$ produced smooth Pt overlayers on the octahedral PtNi nanoparticles. When the same synthesis condition was applied for the commercial Pt/C, the Pt was successfully deposited resulting in the particle size increase from $3.13 \mathrm{~nm}$ to 3.77 $\mathrm{nm}$ as shown in Figure S4.

The Pt electronic structure was investigated using X-ray absorption near-edge structure (XANES) as shown in Figure 4. The Pt L3 edge white line intensity in the XANES indicates the transition of electrons from $2 \mathrm{p}_{2 / 3}$ to $5 \mathrm{~d}$ orbitals. As the white line intensity is lower, the $\mathrm{Pt}$ 
has a more reduced state. The binding of surface oxygen species is affected by the Pt electronic structure significantly, resulting in different ORR activities. Figure 4 shows that the as-made $\mathrm{PtNi} / \mathrm{C}$ has the most metallic character while the commercial $\mathrm{Pt} / \mathrm{C}$ is the most oxidic. The $\mathrm{PtNi} @ \mathrm{Pt} / \mathrm{C}$ showed the white line intensity located between the as-made PtNi/C and the commercial Pt/C.

\subsection{Half-cell tests}

Figure 5 shows the cyclic voltammetry (CV) graphs for the as-made $\mathrm{PtNi} / \mathrm{C}$ and $\mathrm{PtNi} @ \mathrm{Pt} / \mathrm{C}$ catalysts. The electrochemically active surface area (ECSA) decreased a little from $38.1 \mathrm{~m}^{2} \mathrm{~g}^{-}$ ${ }_{\mathrm{Pt}}^{1}$ for the as-made PtNi/C to $33.9 \mathrm{~m}^{2} \mathrm{~g}^{-1} \mathrm{Pt}$ after the deposition of Pt overlayers. The potential for the reduction of surface oxygen species was $0.767 \mathrm{~V}$ for the as-made PtNi, and the potential increased to $0.804 \mathrm{~V}$ for the PtNi@Pt catalyst. The oxygen species such as Pt-O and Pt-OH, which behave as reaction intermediates during oxygen reduction reaction (ORR) and as catalyst-poisoning species, were more easily removed with lower over-potentials from the $\mathrm{Pt}$ surface in the PtNi@Pt catalyst. The activity and durability for the ORR were measured using linear sweep voltammetry (LSV) for the as-made PtNi/C and the PtNi@Pt/C catalysts. The initial mass and specific activity of the PtNi@Pt was $1.24 \mathrm{~A} \mathrm{mg}^{-1} \mathrm{Pt}$ and $3.66 \mathrm{~mA} \mathrm{~cm}^{-2}$ at $0.9 \mathrm{~V}$ in $\mathrm{O}_{2}$ saturated $0.1 \mathrm{M} \mathrm{HClO}_{4}$ solution. These values were higher than those of the as-made PtNi (0.92 $\mathrm{A} \mathrm{mg}^{-1} \mathrm{Pt}, 2.42 \mathrm{~mA} \mathrm{~cm}^{-2}$ ) and of commercial Pt/C (0.22 $\left.\mathrm{A} \mathrm{mg}^{-1} \mathrm{Pt}, 0.25 \mathrm{~mA} \mathrm{~cm}{ }^{-2}\right)$. It was previously reported that three overlayers of $\mathrm{Pt}$ deposited on $\mathrm{Pt}_{3} \mathrm{Ni}$ (111) surface would have the best electronic structure for the ORR by density functional theory (DFT) calculations [45]. The octahedral PtNi@Pt/C with 2.2 Pt overlayers would have better electronic structure for the ORR, comparing to the octahedral PtNi/C or commercial Pt/C catalysts. The enhanced activity of Pt overshell for the ORR was also reported in Pd@Pt nanooctahedra [46].

The durability of the PtNi@Pt/C was tested by repeating the $\mathrm{CV}$ in the range of $0.6 \sim 1.0$ 
V for 5,000 or 10,000 cycles in $\mathrm{O}_{2}$-saturated $0.1 \mathrm{M} \mathrm{HClO}_{4}$ solution. After 10,000 cycles of the accelerated durability test (ADT), the half-wave potential of the as-made $\mathrm{PtNi} / \mathrm{C}$ decreased by $62 \mathrm{mV}$, whereas the PtNi@Pt/C decreased only by $29 \mathrm{mV}$. The ECSA of the as-made PtNi/C decreased more significantly than the PtNi@Pt/C after the ADT. The initial ECSA of the asmade PtNi/C was $38.1 \mathrm{~m}^{2} \mathrm{~g}^{-1}$, then it was degraded to $26.1 \mathrm{~m}^{2} \mathrm{~g}^{-1}$ after 10,000 cycles. In contrast, the ECSA of the PtNi@Pt/C changed from 33.9 to $30.2 \mathrm{~m}^{2} \mathrm{~g}^{-1}$. The Pt surface in the PtNi@Pt/C catalyst was preserved well. When the ORR activity was compared after 10,000 cycles, the activity was $0.38 \mathrm{~A} \mathrm{mg}^{-1} \mathrm{Pt}$ and $1.27 \mathrm{~mA} \mathrm{~cm}^{-2}$ at $0.9 \mathrm{~V}$ for the PtNi@Pt/C, and $0.17 \mathrm{~A} \mathrm{mg}^{-1} \mathrm{Pt}$ and $0.65 \mathrm{~mA} \mathrm{~cm}^{-2}$ for the as-made PtNi/C catalysts. The PtNi@Pt/C showed better durability than the as-made PtNi/C clearly. Figure S5 shows the ADT results of the commercial Pt/C for the ORR. The mass and specific activity were degraded into $0.11 \mathrm{~A} \mathrm{mg}^{-1} \mathrm{Pt}$ and $0.22 \mathrm{~mA} \mathrm{~cm}^{-2}$ after 10,000 cycles.

Figure 6 shows TEM and HR-TEM images of the as-made PtNi/C and the PtNi@Pt/C catalysts after 10,000 cycles. The octahedral shape of the as-made PtNi nanoparticles was severely degraded by Ni leaching in the acidic solution. Most of the nanoparticles became spherical. However, the PtNi@Pt nanoparticles preserved the octahedral shape even after 10,000 cycles. The concentration of leached Ni or Pt ions after 10,000 cycles were measured using ICP-MS. The Ni concentration in the electrolyte for the as-made PtNi/C was $2.67 \mathrm{ppb}$, and the value for the PtNi@Pt/C was $0.96 \mathrm{ppb}$. Ni atoms were dissolved from the as-made $\mathrm{PtNi} / \mathrm{C}$ after 10,000 cycles, whereas Ni atoms were leached less from the PtNi@ Pt/C. The Ni leaching was reduced significantly by the Pt overlayers, enhancing the durability of the PtNi octahedral nanoparticles.

\subsection{Single-cell tests}

A single cell was fabricated using the octahedral PtNi@Pt/C catalyst by a catalyst coated 
membrane $(\mathrm{CCM})$ method. Figure 7 shows the I-V polarization curves for the $\mathrm{PtNi} @ \mathrm{Pt} / \mathrm{C}$ and commercial Pt/C catalysts in $\mathrm{H}_{2} / \mathrm{O}_{2}$ or $\mathrm{H}_{2} /$ air gas flow. When the as-made $\mathrm{PtNi} / \mathrm{C}$ was used for a single cell fabrication, the cell was degraded quickly due to severe Ni leaching. The $\mathrm{PtNi} @ \mathrm{Pt} / \mathrm{C}$ showed higher current density than the commercial Pt/C in both $\mathrm{O}_{2}$ and air flow. In the $\mathrm{O}_{2}$ flow, the PtNi@Pt/C exhibited a current density of $3.1 \mathrm{~A} \mathrm{~cm}^{-2}$ at $0.6 \mathrm{~V}$ and a maximum power density of $2.4 \mathrm{~W} \mathrm{~cm}^{-2}$, whereas the commercial $\mathrm{Pt} / \mathrm{C}$ showed $2.5 \mathrm{~A} \mathrm{~cm}^{-2}$ and $2.1 \mathrm{~W} \mathrm{~cm}^{-}$ ${ }^{2}$. In the air flow, the current density at $0.6 \mathrm{~V}$ and the maximum power density were $2.1 \mathrm{~A} \mathrm{~cm}^{-}$ 2 and $1.4 \mathrm{~W} \mathrm{~cm}^{-2}$ for the PtNi@Pt/C, and $1.7 \mathrm{~A} \mathrm{~cm}^{-2}$ and $1.4 \mathrm{~W} \mathrm{~cm}^{-2}$ for the commercial Pt/C. Figure S6 shows the electrochemical impedance spectroscopy (EIS) results for the PtNi@Pt/C and the commercial Pt/C in the single cells. The charge transfer resistance $\left(\mathrm{R}_{\mathrm{ct}}\right)$ of $\mathrm{PtNi} @ \mathrm{C}$ is about $30 \%$ lower than that of commercial $\mathrm{Pt} / \mathrm{C}$ in both $\mathrm{O}_{2}$ and air flow. These results are evidences of excellent performance in the low current density region of the $\mathrm{I}-\mathrm{V}$ polarization curves.

The durability of the single cells was tested by following the DOE protocol. The ADT was performed at a scan rate of $50 \mathrm{mV} \mathrm{s}^{-1}$ from $0.6 \mathrm{~V}$ to $1.0 \mathrm{~V}$ for 30,000 cycles with a cathode feed of $\mathrm{N}_{2}$ with $100 \%$ relative humidity. The current density at $0.6 \mathrm{~V}$ and maximum power density after 30,000 cycles of the ADT were $1.8 \mathrm{~A} \mathrm{~cm}^{-2}$ and $1.5 \mathrm{~W} \mathrm{~cm}^{-2}$ for the PtNi@Pt/C, and $1.2 \mathrm{~A}$ $\mathrm{cm}^{-2}$ and $1.3 \mathrm{~W} \mathrm{~cm}^{-2}$ for the commercial $\mathrm{Pt} / \mathrm{C}$ in $\mathrm{O}_{2}$ flow. The EIS results after the ADT under $\mathrm{O}_{2}$ and air conditions elucidated that the $\mathrm{R}_{\mathrm{ct}}$ of the PtNi@Pt/C was lower than that of commercial Pt/C in Figure S6. Also, the ECSA decreased by $22.1 \%$ in the PtNi@Pt/C, whereas it decreased by $33.7 \%$ in the commercial Pt/C as shown in Figure S7. It was clearly identified that the durability of the PtNi@Pt/C was improved by the Pt overlayers. Surely, the octahedral $\mathrm{PtNi} @ \mathrm{Pt} / \mathrm{C}$ showed higher activity and durability than the commercial Pt/C even in the single cells. 


\section{Conclusion}

Octahedral PtNi nanoparticles with Pt overlayers (PtNi@Pt) were synthesized on the carbon support at a gram-scale. The gas-phase synthesis method was used for the synthesis of octahedral PtNi nanoparticles using $\mathrm{CO}$ as a shaping agent, subsequently Pt overlayers were deposited using $\mathrm{Cu}$ UPD and Pt galvanic replacement. The octahedral PtNi@Pt/C catalyst showed better activity and durability in both half cell and full cell tests than the commercial Pt/C. In a half cell test, the PtNi@Pt/C catalyst was 5.6 times more active than the commercial Pt/C initially and 3.3 times more active after the ADT for 10,000 cycles when the mass activity at $0.9 \mathrm{~V}$ was compared. In a single cell test, the PtNi@Pt/C catalyst was 1.2 times more active than the commercial Pt/C initially and 1.5 times more active after the ADT for 30,000 cycles when the current density at $0.6 \mathrm{~V}$ in $\mathrm{O}_{2}$ flow was compared. Although most works using octahedral PtNi nanoparticles for the ORR have focused on the half cell tests, the octahedral PtNi@Pt nanoparticles could be successfully used in the single cell, with enhanced activity and durability.

\section{Acknowledgements}

This work was supported by the Global Frontier R\&D Program of Center for Multiscale Energy System (2011-0031570 and 2016M3A6A7945505) and 2015R1A2A2A01004467 through the National Research Foundation of Korea. 


\section{References}

[1] M.K. Debe, Nature, 486 (2012) 43-51.

[2] N.M. Markovic, H.A. Gasteiger, P.N. Ross, J. Phys. Chem., 99 (1995) 3411-3415.

[3] J.R. Kitchin, J.K. Norskov, M.A. Barteau, J.G. Chen, J. Chem. Phys., 120 (2004) 1024010246.

[4] J.R. Kitchin, J.K. Norskov, M.A. Barteau, J.G. Chen, Phys. Rev. Lett., 93 (2004) 156801.

[5] J.K. Norskov, J. Rossmeisl, A. Logadottir, L. Lindqvist, J.R. Kitchin, T. Bligaard, H. Jonsson, J. Phys. Chem. B, 108 (2004) 17886-17892.

[6] E. Antolini, J. Salgado, M. Giz, E. Gonzalez, Int. J. Hydrogen Energy, 30 (2005) 1213-1220.

[7] V. Stamenkovic, B.S. Mun, K.J.J. Mayrhofer, P.N. Ross, N.M. Markovic, J. Rossmeisl, J. Greeley, J.K. Nørskov, Angew. Chem. Int. Ed., 45(18) (2006) 2897-2901.

[8] T. Bligaard, J.K. Nørskov, Electrochim. Acta, 52 (2007) 5512-5516.

[9] J.B. Joo, Y.J. Kim, W. Kim, N.D. Kim, P. Kim, Y. Kim, Y.-W. Lee, J. Yi, Korean J. Chem. Eng., 25 (2008) 431-436.

[10] J.K. Norskov, T. Bligaard, B. Hvolbaek, F. Abild-Pedersen, I. Chorkendorff, C.H. Christensen, Chem. Soc. Rev., 37 (2008) 2163-2171.

[11] J. Shin, J.H. Choi, P.R. Cha, S.K. Kim, I. Kim, S.C. Lee, D.S. Jeong, Nanoscale, 7 (2015) 15830-15839.

[12] S. Yang, D.Y. Chung, Y.-J. Tak, J. Kim, H. Han, J.-S. Yu, A. Soon, Y.-E. Sung, H. Lee, Appl. Catal. B-Environ., 174-175 (2015) 35-42.

[13] J. Kim, S. Yang, H. Lee, Electrochem. Commun., 66 (2016) 66-70.

[14] V.R. Stamenkovic, B. Fowler, B.S. Mun, G. Wang, P.N. Ross, C.A. Lucas, N.M. Markovic, Science, 315 (2007) 493-497.

[15] J. Wu, H. Yang, Nano Res., 4 (2010) 72-82.

[16] J. Zhang, H. Yang, J. Fang, S. Zou, Nano Lett., 10 (2010) 638-644.

[17] J. Wu, A. Gross, H. Yang, Nano Lett., 11 (2011) 798-802.

[18] M.K. Carpenter, T.E. Moylan, R.S. Kukreja, M.H. Atwan, M.M. Tessema, J. Am. Chem. Soc., 134 (2012) 8535-8542. 
[19] C. Cui, L. Gan, H.H. Li, S.H. Yu, M. Heggen, P. Strasser, Nano Lett., 12 (2012) 5885 5889.

[20] J. Wu, L. Qi, H. You, A. Gross, J. Li, H. Yang, J. Am. Chem. Soc., 134 (2012) 1188011883.

[21] Y. Wu, D. Wang, Z. Niu, P. Chen, G. Zhou, Y. Li, Angew. Chem. Int. Ed. Engl., 51 (2012) 12524-12528.

[22] S.I. Choi, S. Xie, M. Shao, J.H. Odell, N. Lu, H.C. Peng, L. Protsailo, S. Guerrero, J. Park, X. Xia, J. Wang, M.J. Kim, Y. Xia, Nano Lett., 13 (2013) 3420-3425.

[23] C. Chen, Y. Kang, Z. Huo, Z. Zhu, W. Huang, H.L. Xin, J.D. Snyder, D. Li, J.A. Herron, M. Mavrikakis, M. Chi, K.L. More, Y. Li, N.M. Markovic, G.A. Somorjai, P. Yang, V.R. Stamenkovic, Science, 343 (2014) 1339-1343.

[24] X.Q. Huang, Z.P. Zhao, Y. Chen, E.B. Zhu, M.F. Li, X.F. Duan, Y. Huang, Energy. Environ. Sci., 7 (2014) 2957-2962.

[25] C. Zhang, S.Y. Hwang, A. Trout, Z. Peng, J. Am. Chem. Soc., 136 (2014) 7805-7808.

[26] X.Q. Huang, Z.P. Zhao, L. Cao, Y. Chen, E.B. Zhu, Z.Y. Lin, M.F. Li, A.M. Yan, A. Zettl, Y.M. Wang, X.F. Duan, T. Mueller, Y. Huang, Science, 348 (2015) 1230-1234.

[27] J. Choi, Y. Lee, J. Kim, H. Lee, J. Power Sources, 307 (2016) 883-890.

[28] H.R. Colón-Mercado, B.N. Popov, J. Power Sources, 155 (2006) 253-263.

[29] N. Hodnik, M. Zorko, M. Bele, S. Hočevar, M. Gaberšček, J. Phys. Chem. C, 116 (2012) 21326-21333.

[30] C. Cui, L. Gan, M. Heggen, S. Rudi, P. Strasser, Nat. Mater., 12 (2013) 765-771.

[31] M. Tada, T. Uruga, Y. Iwasawa, Catal. Lett., 145 (2015) 58-70.

[32] J. Zhang, Y. Mo, M.B. Vukmirovic, R. Klie, K. Sasaki, R.R. Adzic, J. Phys. Chem. B, 108 (2004) 10955-10964.

[33] J. Zhang, F.H.B. Lima, M.H. Shao, K. Sasaki, J.X. Wang, J. Hanson, R.R. Adzic, J. Phys. Chem. B, 109 (2005) 22701-22704.

[34] R.R. Adzic, J. Zhang, K. Sasaki, M.B. Vukmirovic, M. Shao, J.X. Wang, A.U. Nilekar, M. Mavrikakis, J.A. Valerio, F. Uribe, Top. Catal., 46 (2007) 249-262.

[35] T. Ghosh, M.B. Vukmirovic, F.J. DiSalvo, R.R. Adzic, J. Am. Chem. Soc., 132 (2010) 
906-907.

[36] S. Yang, H. Lee, ACS Catalysis, 3 (2013) 437-443.

[37] M. Inaba, H. Daimon, J. Jpn Petrol. Inst., 58 (2015) 55-63.

[38] A. Oh, H. Baik, D.S. Choi, J.Y. Cheon, B. Kim, H. Kim, S.J. Kwon, S.H. Joo, Y. Jung, K. Lee, ACS Nano, 9 (2015) 2856-2867.

[39] R.M. Arán-Ais, J. Solla-Gullón, M. Gocyla, M. Heggen, R.E. Dunin-Borkowski, P. Strasser, E. Herrero, J.M. Feliu, Nano Energy, 27 (2016) 390-401.

[40] W.P. Davey, Phys. Rev., 25 (1925) 753-761.

[41] C. Kim, J.-G. Oh, Y.-T. Kim, H. Kim, H. Lee, Electrochem. Commun., 12 (2010) 15961599.

[42] H. Zhang, M. Jin, Y. Xia, Chem. Soc. Rev., 41 (2012) 8035-8049.

[43] J. Park, J. Liu, H.C. Peng, L. Figueroa-Cosme, S. Miao, S.I. Choi, S. Bao, X. Yang, Y. Xia, ChemSusChem, 9 (2016) 2209-2215.

[44] S. Xie, S.I. Choi, N. Lu, L.T. Roling, J.A. Herron, L. Zhang, J. Park, J. Wang, M.J. Kim, Z. Xie, M. Mavrikakis, Y. Xia, Nano Lett., 14 (2014) 3570-3576.

[45] L. Cao, T. Mueller, J. Phys. Chem. C, 119 (2015) 17735-17747.

[46] J. Park, L. Zhang, S.-I. Choi, L.T. Roling, N. Lu, J.A. Herron, S. Xie, J. Wang, M.J. Kim, M. Mavrikakis, Y. Xia, ACS Nano, 9 (2015) 2635-2647. 

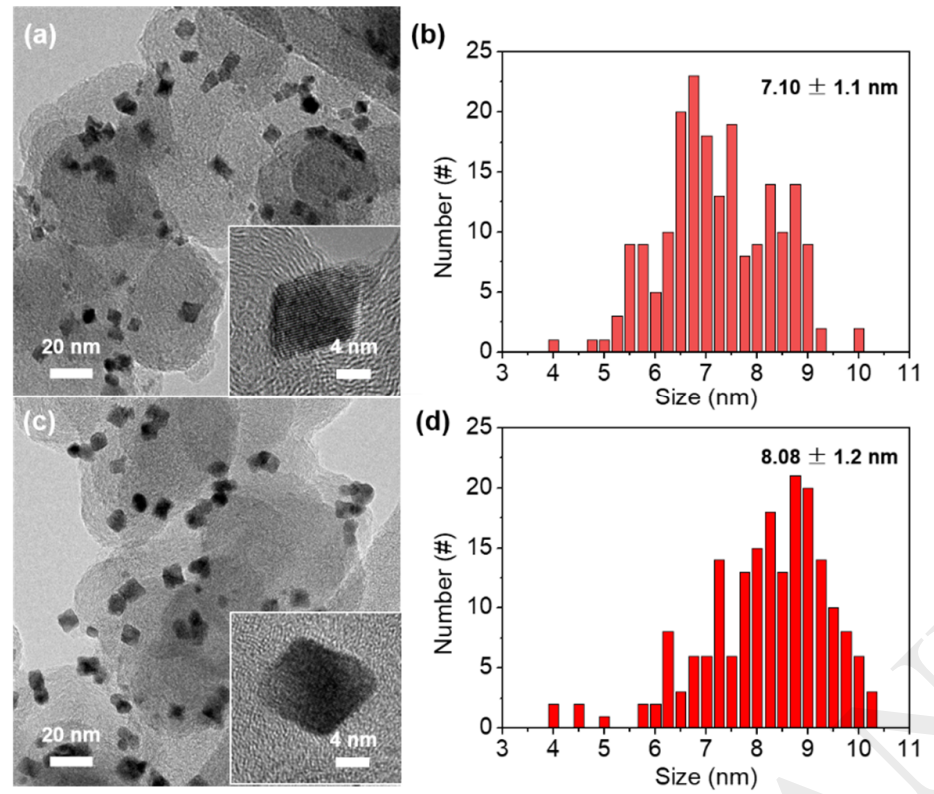

Figure 1. TEM images and nanoparticle size histograms for the (a, b) as-made PtNi/C and (c, d) PtNi@Pt/C catalysts 

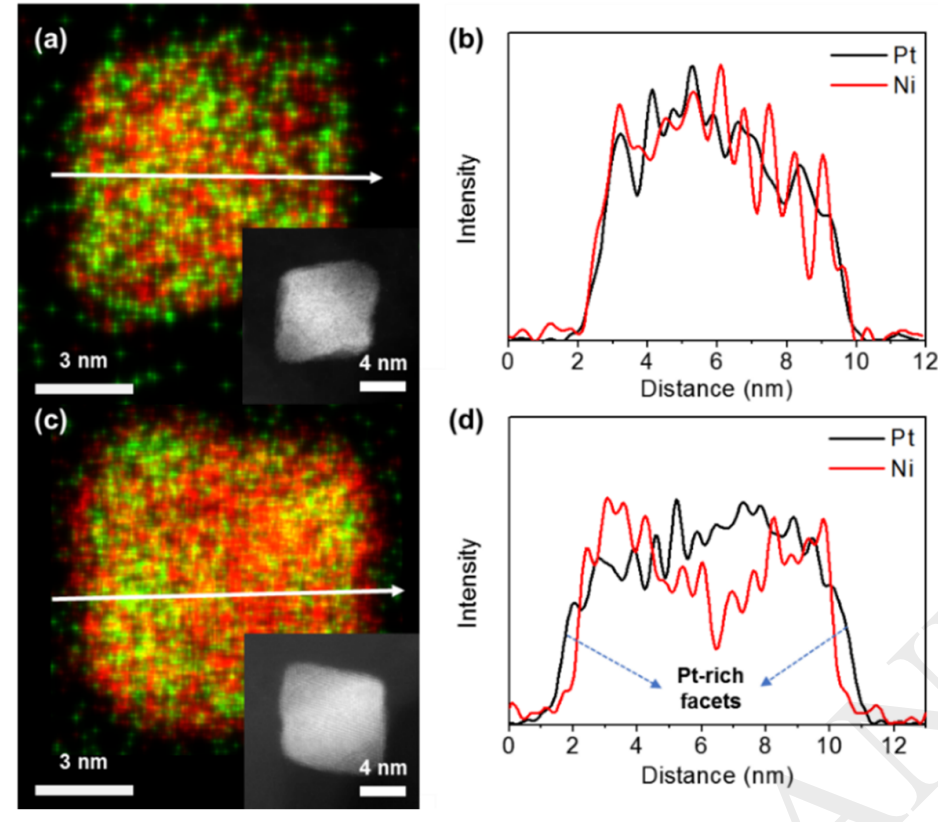

Figure 2. EDS-mapping (red: Pt, green: Ni) and elemental line-scanning images for a single nanoparticle of the (a, b) as-made PtNi and (c, d) PtNi@Pt catalysts. 


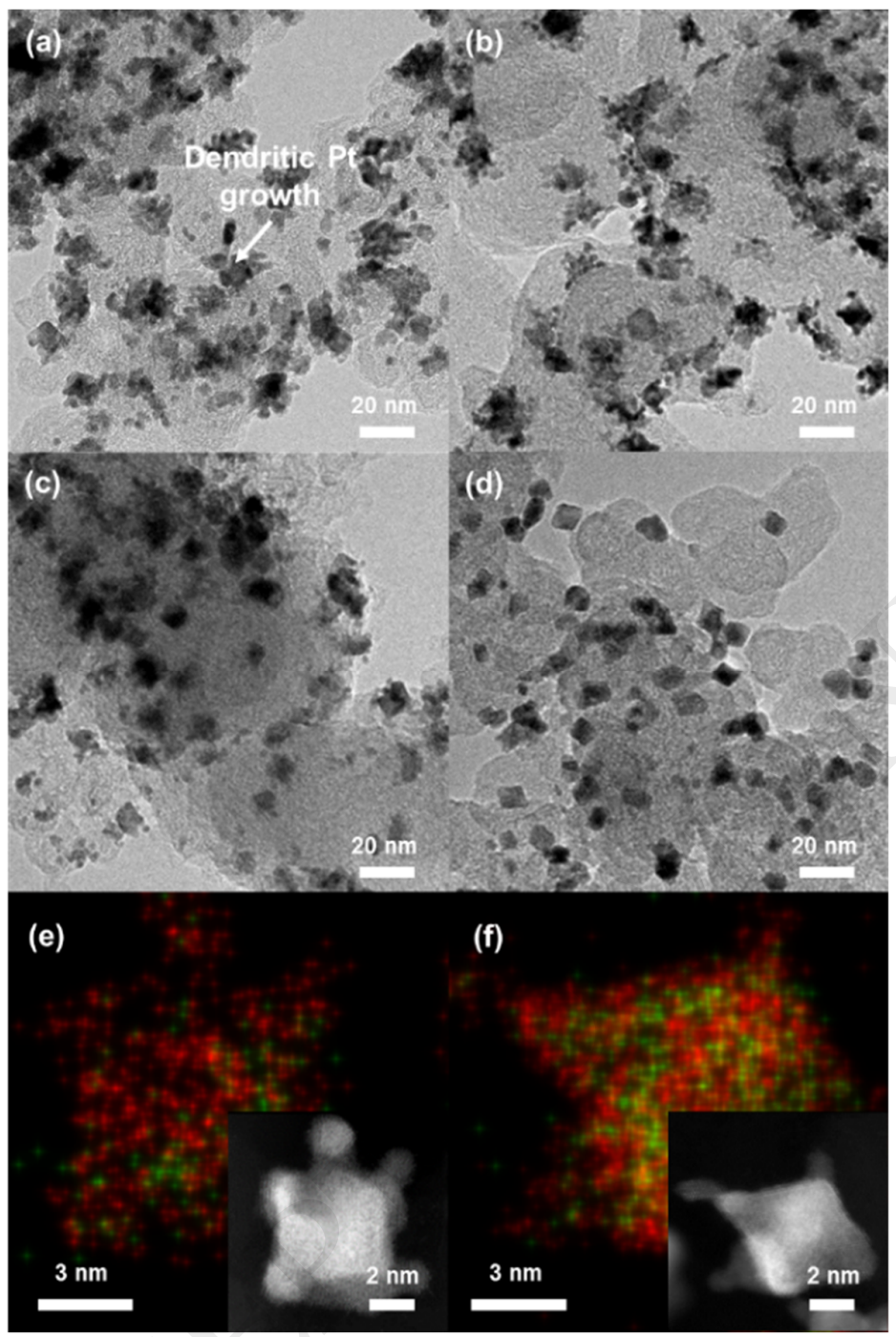

Figure 3. TEM images of the nanoparticles when (a) $0.5 \mathrm{mM}$, (b) $0.1 \mathrm{mM}$, (c) $0.06 \mathrm{mM}$, and (d) $0.05 \mathrm{mM}$ of $\mathrm{K}_{2} \mathrm{PtCl}_{4}$ solution were used during Pt galvanic replacement at $800 \mathrm{RPM}$. (e,f) EDS-mapping images of the dendrite nanoparticle synthesized using $0.5 \mathrm{mM} \mathrm{K}_{2} \mathrm{PtCl}_{4}$ solution (Red: Pt, Green: Ni, inset: HAADF-STEM image). 


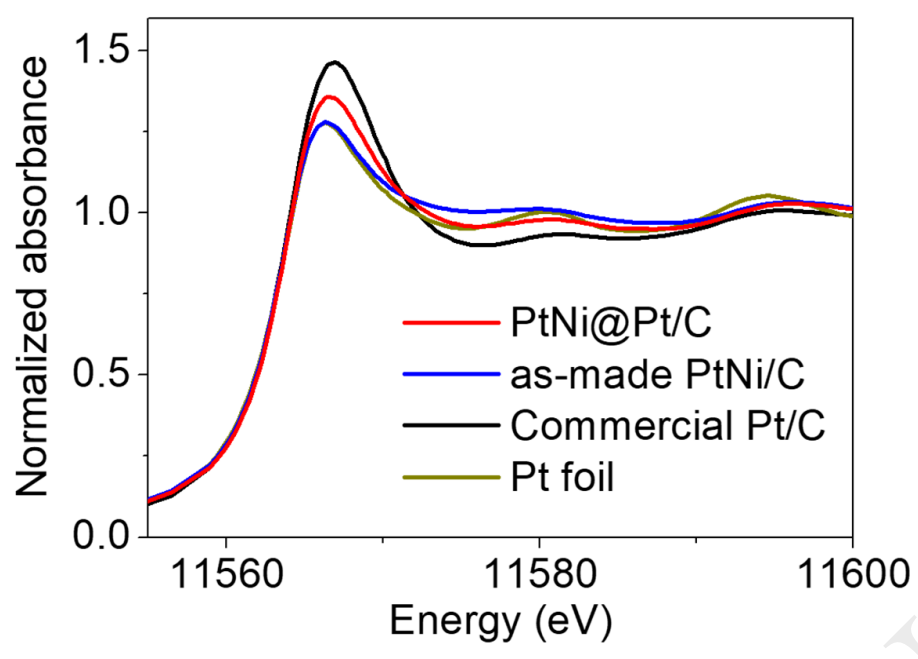

Figure 4. XANES results of the as-made $\mathrm{PtNi} / \mathrm{C}, \mathrm{PtNi} @ \mathrm{Pt} / \mathrm{C}$, and commercial Pt/C catalysts. 

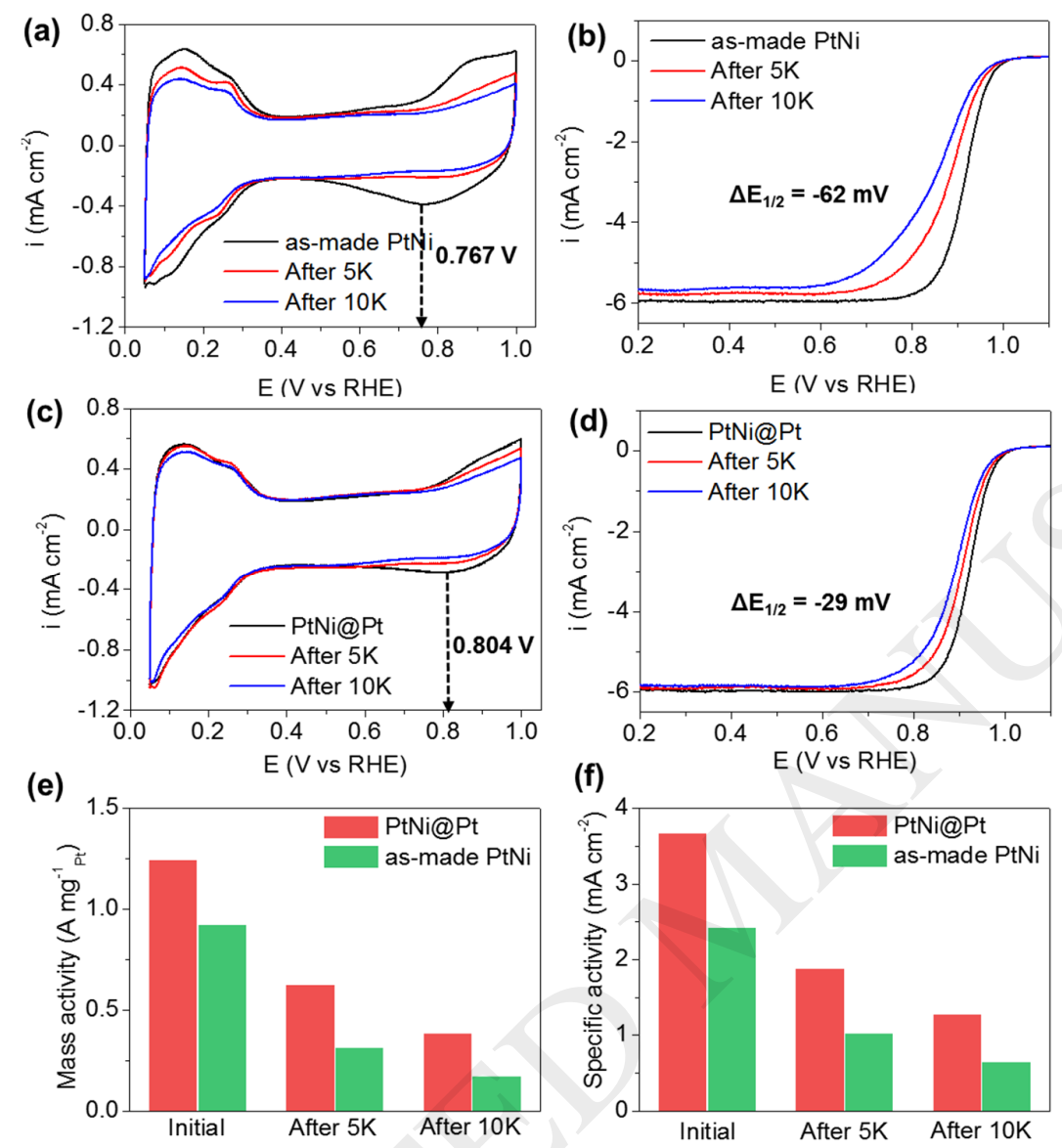

Figure 5. (a, c) Cyclic voltammograms, (b, d) linear sweep voltammetry curves, and (e, f) the mass activities and specific activities for the as-made PtNi/C and PtNi@Pt/C catalysts. The ADT was performed in the range of $0.6-1.0 \mathrm{~V}$ at a scan rate of $100 \mathrm{mV} \mathrm{s}^{-1}$. 


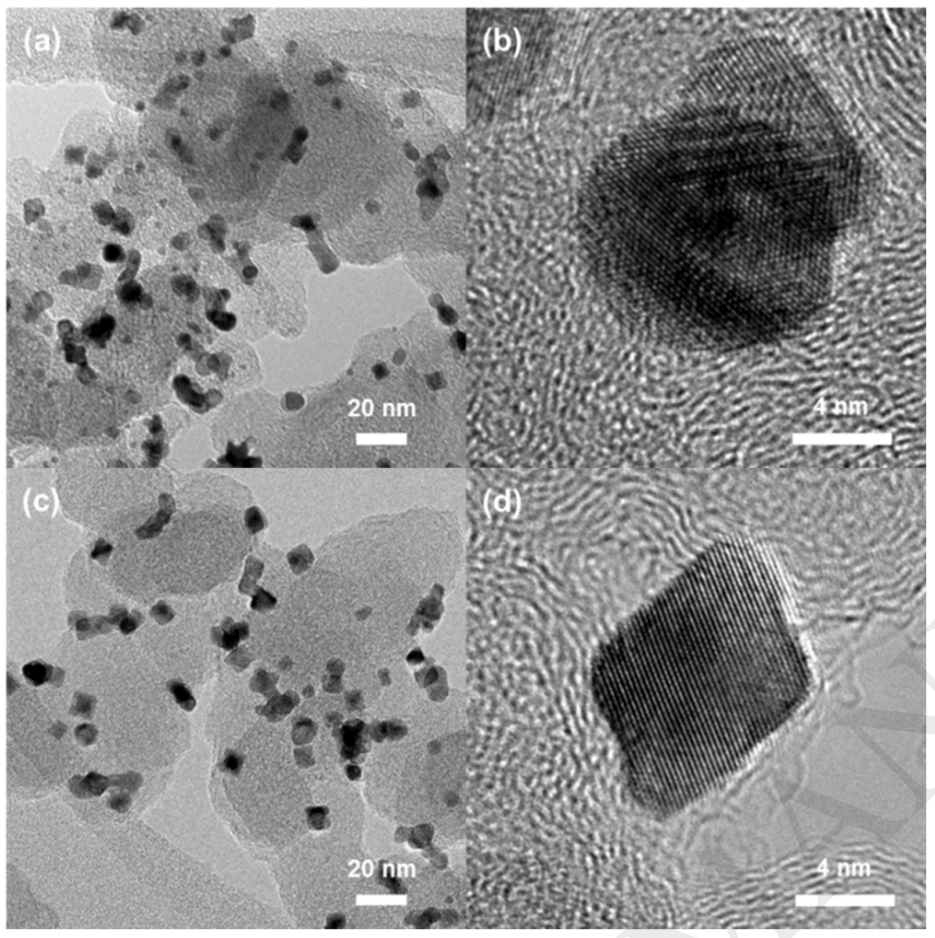

Figure 6. TEM and HR-TEM images of the (a, b) as-made PtNi/C and (c, d) PtNi@Pt/C after 10,000 cycles of the ADT. 

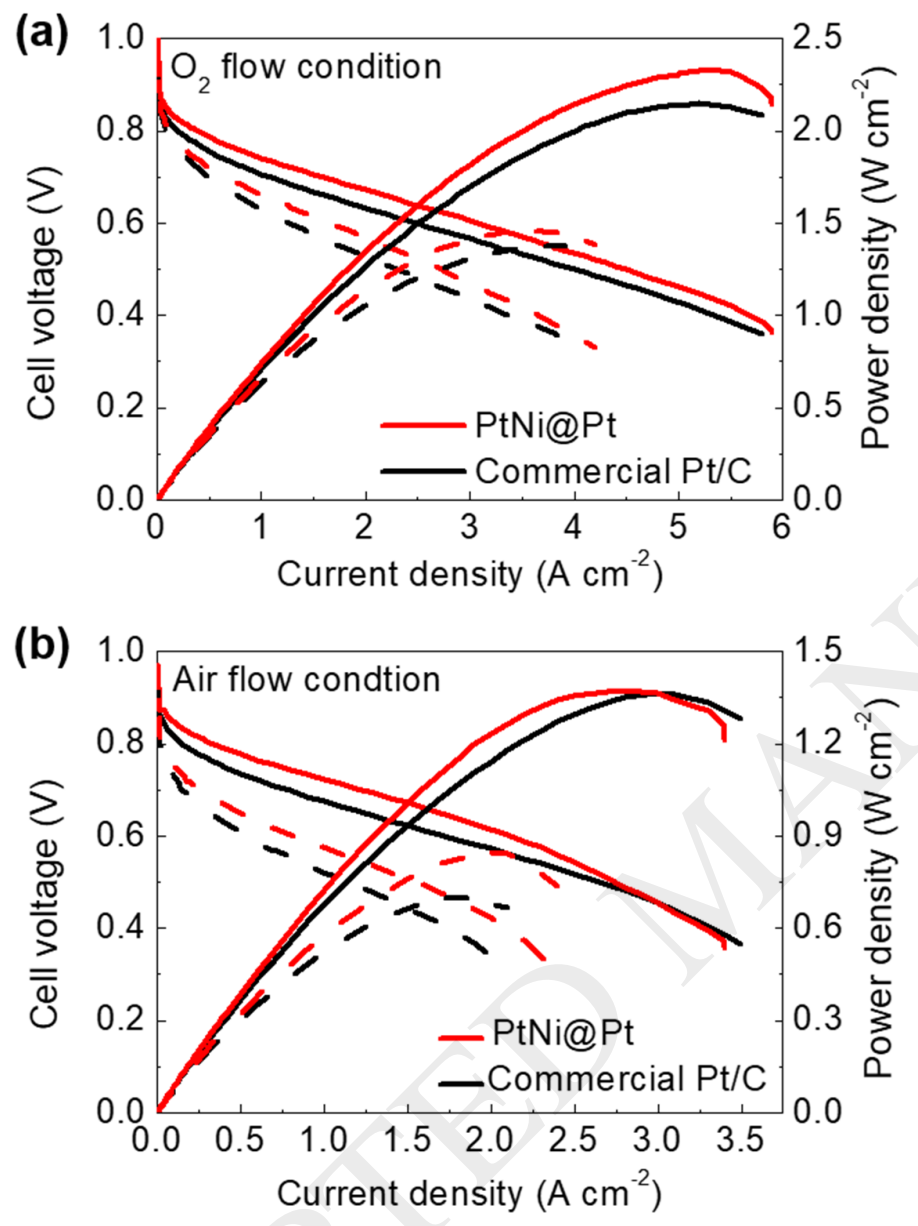

Figure 7. Single cell I-V polarization curves of the fresh catalysts (solid lines) or after 30,000 cycles of the ADT (dashed lines) for the PtNi@Pt/C and commercial Pt/C catalysts in (a) $\mathrm{O}_{2}$ or (b) air flow at the cathode. 